\title{
Problems That Are Faced by Students While Doing Their Entrepreneurship Projects: A Survey Conducted in Business Schools in Jabodetabek (Jakarta, Bogor, Depok, Tangerang and Bekasi)
}

\author{
Kerenhapukh Sugiarto, Honey Naresh Samtani, Stephanie Louissa Amaris, and Suresh Kumar
}

\begin{abstract}
Since entrepreneurship has become the biggest issue in many countries, Universities robustly introduce entrepreneurship skill not only for the business school students, but other majors as well. Universities have developed a real-life project of starting-up a business project in a determined period of time. Objective of this project is designed to develop an entrepreneurial mindset. This paper concisely highlights the issues faced by students doing entrepreneurship project in these fields i.e., production, management, finance, marketing, and technology. A quantitative survey method was chosen to explore the issues appropriately in Indonesia to increase the number of entrepreneurs which is currently $1.5 \%$ from the total population of Indonesia. This research conducted in Jakarta, Bogor, Depok, Tangerang, Bekasi (Jabodetabek - Indonesia) with a total of 280 respondents as sample. This paper is expected to further give field-tested recommendations for university authorities to give a better guidance of entrepreneurial projects for the students.
\end{abstract}

Index Terms-Business, entrepreneurship, entrepreneurship project, students, university.

\section{INTRODUCTION}

A topic which attracts the most attention among academicians and journalists is Entrepreneurship. Researchers have been focusing on the function of an entrepreneur which is to serve the economy [1]. The concept of entrepreneurship can be understood as a process of vision, change and creation. The act of entrepreneurship needs a certain amount of energy and passion to create and implement new ideas. There seems to be an agreement that the act of entrepreneurship involves creating something new [2]. In addition, entrepreneurship can be interpreted as a "process" rather than one-time event, action or decision. It is all based on the level of creativity a person has to uncover new ideas and also to arrange the resources in ways that have not been done before [3].

Based on Indonesia Central Board of Statistics [4], there are a total of 3.75 million entrepreneurs in Indonesia or about $1.58 \%$ of the total Indonesian population. This number is still small compared to China, Japan, which has

Manuscript received December 25, 2013; revised March 31, 2014. This work was supported in part by the President University.

The authors are with Faculty of Business, President University, Jababeka, Cikarang, Indonesia (e-mail: kerensugiarto@aol.com, honey_samtani@yahoo.com,

sureshkumar@president.ac.id).
$10 \%$ entrepreneurs respectively from the population in 2012 . The prosperity of a country can be achieved if the country has at least $2 \%$ of entrepreneurs in their country's population [5]. Entrepreneurship is an important concept for discovering opportunities and stimulating growth. In order to decrease unemployment rate in Indonesia and stimulate economic growth as found by Acs et al. [6] in finding a positive relationship between entrepreneurship and economic development. Entrepreneurial spirit should be fostered from an early age in order to continue Indonesia's economic growth.

This is an explanatory about a way to prepare the students in doing their entrepreneurship projects and real business in the future. The explanatory is discussing about the most common problems faced by students while doing their entrepreneurship projects. Other than that, this research will provide a detailed explanation of entrepreneurship and its importance. As business schools students, we know that students in some business schools are given a project to open a business and this project is called as entrepreneurship project. Therefore, we analyze the problems faced by students while doing their entrepreneurship project and the solution they come up with during their project.

\section{REVIEW OF LITERATURE}

\section{A. Entrepreneurship}

An entrepreneur is a person who takes a decision to employ himself to be the innovator and creator of new enterprises [7] and a new economic activity [8]. Besides that, the act of entrepreneurship doesn't only consist of constructing a new business or firm but also in organizing the capital and other needs in the business. Successful entrepreneurship depends on the skill to take chances to gain advantage from available technology [9] and all the opportunities that can be achieved in the future [10]. For instance, Shane [3] provides the foundation for defining entrepreneurial behavior as a behavior of a person which is good at decision making, able to combine ideas and making things happen instead of waiting for things to happen.

\section{B. The Need for Entrepreneurs}

The contribution made by entrepreneurs can be in a form of benefits given to the society by reallocating resources from less to more productive uses [11] by performing 'costdiscovery', 'gap-filling', and 'input-completing' functions in the economy [12]. These roles have been the main subject of 
a growing economy [13]. This concept stands under general perception that companies directed by entrepreneurs tend to be job creators and the reason for economic growth. The fact that entrepreneurs have been a great influence towards the economy has not changed from the past until now. For instance, employees receive the benefit from the income they earn from the business growth and success. Finally, employees can become the prospect customers with the purchasing power to purchase the goods and services produced by the entrepreneur. Due to this, many entrepreneurs today aims on improving the society [14]. The society interconnects with entrepreneurship because entrepreneurship produces for the society. Thus, they are complementary and as the society evolves, entrepreneurship continues to change [15].

\section{The Role of Entrepreneurship Projects in Business Schools}

The purpose of entrepreneurship education is for students to learn for entrepreneurship, learn about entrepreneurship and learning through entrepreneurship [16]. Thus, the entrepreneurship education acts as both method of learning as well as a content of learning [17]. In context with entrepreneurship education, Gibb [16] had found some differences between enterprising behavior and entrepreneurial behavior, which is enterprising can be used in any context while entrepreneurial mainly points out the business activity. By learning the entrepreneurship education and doing the entrepreneurship project, students are ready if they want to choose entrepreneurship as a career choice because the entrepreneurship education helps them to attain the skills needed to be an entrepreneur [18], [19]. In other words, through the entrepreneurship projects student will be able to experience being a real entrepreneur, try harder to achieve their goals, take opportunities and adapt with the environment.

\section{Problems That Students Face in Their Entrepreneurship Projects}

Firms which have just enter the market will have some problems with the existing firms, this is because customers have become loyal for the existing firms and aren't aware of the new firms. Problems that will be faced by entrepreneurs are not always clear but usually the causes are business operations and services problems, motivation and demand problems, financial problems, management problems and networking problems [20].

\section{1) Financial problems}

According to Reinhart and Rogoff [21], financial problems are the same as a disturbance in taking an opportunity. They can come from many internal and external origins and start from different sectors. For instance, financial problems may occur if there is an increase in living cost and no increase in income [22]. Unplanned spending is also one of the causes to be the cause of financial problems. In the entrepreneurship project, students face problems which are similar to the problems faced by small businesses [23].

$\mathrm{H}_{1}$ : The relationship of financial problems with entrepreneurship projects.

\section{2) Management problems}

The management theory considers of two things which are efficiency and effectiveness, in other words, doing things right and doing the right things to achieve organizational goals [24]. Although people learn the theories of entrepreneurship, the students still manage to fail and due to this, it has been concluded that they are born that way, not made [23].

$\mathrm{H}_{2}$ : The relationship of management problems with entrepreneurship projects.

\section{3) Marketing problems}

More than any business function is marketing which deals with the customers. One of the simplest definition of marketing it to manage profitable relation with customers [25]. Marketing can also be defined as the function in an organization for creation, communication and delivery of value to the customers and to maintain relationship with the customer in order to benefit the organization [26]. The problem faced by students during this stage is for the business to create an environment that is tending to produce creativity so that the business can revive [27].

$\mathrm{H}_{3}$ : The relationship of marketing problems with entrepreneurship projects.

\section{4) Production problems}

The simple definition of production is making use of humans and technology to convert raw materials into finished goods and services [28]. It can also be defined as to apply a process to raw materials; this process adds value to the existing product without decreasing the quality [29]. Most students face the problems in the capacity of the stock provided. In the past few years, the innovation of products has become necessary as it has become the director for competitive advantage. By innovating products, students can maintain efficiency and increase the quality of products. A consumer understands innovation as a better and improved quality products which have been made by considering efficiency and effectiveness [30].

$\mathrm{H}_{4}$ : The relationship of marketing problems with entrepreneurship projects

\section{5) Technology problems}

Technology problems are those problems which exists because of the difficulties in using it. Basically, modern life is defined by technology [31]. Many students can improve their level of productivity and increase their profitability by increasing their training in technological department, especially in mastering information technology [32].

$\mathrm{H}_{5}$ : The relationship of technology problems with entrepreneurship projects.

\section{RESEARCH METHOD}

The questionnaire of this research paper was distributed to students of business schools in Jabodetabek (Jakarta, Bogor, Depok, Tangerang, Bekasi) who did their entrepreneurship project. The sampling technique in this research paper was simple random sampling, which is the basic selection process of sampling and is easiest to understand [33].

The proportional size of respondents is 10 respondents per parameter [34], therefore we distributed the 
questionnaires to 280 respondents of business school students who did their entrepreneurship project. The questionnaires were distributed on October $25^{\text {th }}, 2013$ to business school students in Jabodetabek (Jakarta, Bogor, Depok, Tangerang, Bekasi).

The questionnaire distribution tools we used were printed questionnaire and Google Drive. Business students were approached directly to fulfill the printed questionnaire. Moreover, to reach a distance of business students, we sent the questionnaire through Google Drive.

To emphasize the answers of the questionnaire, we define the universities of the respondents and the problems factors while doing entrepreneurship project. We provided 5 points to determine the variables as Likert scale to measure the respondent's degree of agrees or disagrees about the questionnaire statements. The scale consist of $1=$ strongly agree, 2=agree, 3=neutral, 4=disagree, and 5=strongly disagree.

SPSS version 20.0 software was used to support the validity and reliability of the questionnaire. The reliability of the data will be tested through Cronbach's Alpha with a cutoff point 0.7 [35]. Next, to check the validity, a statistical method of factor analysis was used. The independent variables are financial problems, management problems, marketing problems, production problems, and technology problem while the dependent variables are entrepreneurship projects.

A number of 189 respondents came from President University $(67.5 \%)$, the second one was 37 respondents from Bina Nusantara University (13.2\%), the third one was 17 respondents from Prasetya Mulya University (6.07\%), the fourth one was 12 respondents from Atma Jaya University $(4.3 \%)$, the fifth one was 9 respondents from Pelita Harapan University $(3.21 \%)$, the sixth and seventh were 6 respondents from Tarumanegara University and Bogor Agricultural University (2.14\%), and the last one was 4 respondents from Petra Christian University (1.43\%).

\section{MEASURES}

\section{A. Factor Analysis}

TABLE I: KMO AND BARTLETT'S TEST

\begin{tabular}{|c|l|l|}
\hline \multicolumn{2}{|l|}{$\begin{array}{l}\text { Kaiser-Meyer-Olkin Measure of Sampling } \\
\text { Adequacy }\end{array}$} & 0.847 \\
\hline \multirow{2}{*}{$\begin{array}{c}\text { Bartlett's Test of } \\
\text { Sphericity }\end{array}$} & Approx. Chi-Square & 4622.789 \\
\cline { 2 - 3 } & Df & 276 \\
\cline { 2 - 3 } & Sig. & 0.000 \\
\hline
\end{tabular}

The KMO and Bartlett's test is done to determine the factorability of an intercorrelation matrix. From Table I, we can conclude that the data are factorable since the KMO result is 0.847 , and the Bartlett's Test is significance. Thus, the correlation matrix is not an identity matrix [34]. Communalities act as an indicator for the amount of variance in each variable that is accounted for [36]. The marketing 1 variable is deleted because the number of extraction is 0.3 which is not valid because the theories state that if an item has communality less than 0.5 then it might not be related to all items or suggest an additional factor could be added [37].

The total variance explained shows how much of the variability in the data have been influenced by the extracted factors [36]. The method to retain the values for rotation is using the criterion that the eigenvalues of the factors must be 1 or greater, which means, in this case, there were 5 factors that are significant. The results of the 5 factors are $33.594 \%, 13.356 \%, 8.613 \%, 7.081 \%$, and $6.08 \%$ of the total variance. The other 19 factors justified only $\pm 31 \%$. Therefore, those 5 factors are sufficient to represent the data. The criterion for the cumulative percentage is for the amount to be more than $60 \%$, which this research reached $68.712 \%$ [38].

\section{B. Validity and Reliability}

TABLE II: ROTATED COMPONENT MATRIX \& CRONBACH ALPHA

\begin{tabular}{|c|c|c|c|}
\hline & & $\begin{array}{c}\text { Rotated } \\
\text { Component } \\
\text { Matrix }\end{array}$ & $\begin{array}{c}\text { Cronbach } \\
\text { Alpha }\end{array}$ \\
\hline \multirow{11}{*}{$\begin{array}{c}\text { Variable 1 } \\
\text { "Business } \\
\text { Operation and } \\
\text { Service" }\end{array}$} & MKT2 & 0.874 & \multirow[t]{11}{*}{0.961} \\
\hline & MGT2 & 0.864 & \\
\hline & PRO3 & 0.855 & \\
\hline & PRO4 & 0.853 & \\
\hline & MKT5 & 0.852 & \\
\hline & MKT4 & 0.848 & \\
\hline & PRO1 & 0.847 & \\
\hline & PRO2 & 0.836 & \\
\hline & MKT3 & 0.830 & \\
\hline & MGT7 & 0.824 & \\
\hline & MGT1 & 0.816 & \\
\hline & PRO5 & 0.843 & \multirow[t]{3}{*}{0.813} \\
\hline \multirow{3}{*}{$\begin{array}{l}\text { Variable } 2 \\
\text { "Motivation } \\
\text { and Demand" }\end{array}$} & MKT6 & 0.821 & \\
\hline & MGT8 & 0.766 & \\
\hline & MGT3 & 0.725 & (deleted) \\
\hline \multirow{3}{*}{$\begin{array}{l}\text { Variable } 3 \\
\text { "Finance" }\end{array}$} & FIN1 & 0.866 & \multirow[t]{3}{*}{0.733} \\
\hline & FIN3 & 0.778 & \\
\hline & FIN2 & 0.747 & \\
\hline \multirow{3}{*}{$\begin{array}{l}\text { Variable } 4 \\
\text { "Management } \\
\text { " }\end{array}$} & MGT4 & 0.850 & \multirow[t]{3}{*}{0.712} \\
\hline & MGT6 & 0.788 & \\
\hline & MGT5 & 0.721 & \\
\hline \multirow{3}{*}{$\begin{array}{c}\text { Variable 5 } \\
\text { "Networking" }\end{array}$} & TECH 2 & 0.847 & \multirow[t]{2}{*}{0.701} \\
\hline & TECH1 & 0.758 & \\
\hline & MKT7 & -0.602 & (deleted) \\
\hline \multicolumn{2}{|c|}{$\begin{array}{c}\text { Dependent Variable } \\
\text { "Entrepreneurship Project" }\end{array}$} & \multicolumn{2}{|l|}{0.919} \\
\hline
\end{tabular}

The rotated component matrix is also called as the rotated factor matrix in the factor analysis because it shows a matrix of the factor loadings for each variable onto each factor. In this case, the rotated component matrix presents five factors. Factor 1 comprises 11 elements which illustrates that most of these elements signify business operations and services. Factor 2 comprises 4 elements which show that these elements signify motivation and demand in the company. While factor 3 comprises 3 elements which signify financial problems in a company. Factor 4 comprises 3 elements which reflect the management in running a business. Lastly, factor 5 comprises 3 items which signify the networking problems in running a business.

The criteria of the cronbach's alpha are that it must not be below 0.7 and it must be based on rotated component matrix 
[35]. The deleted factors are in the second and fifth variables which are the MGT3 factor and the MKT7 factor. Those factors were deleted in order to make the variables reliable.

\section{Linear Regression}

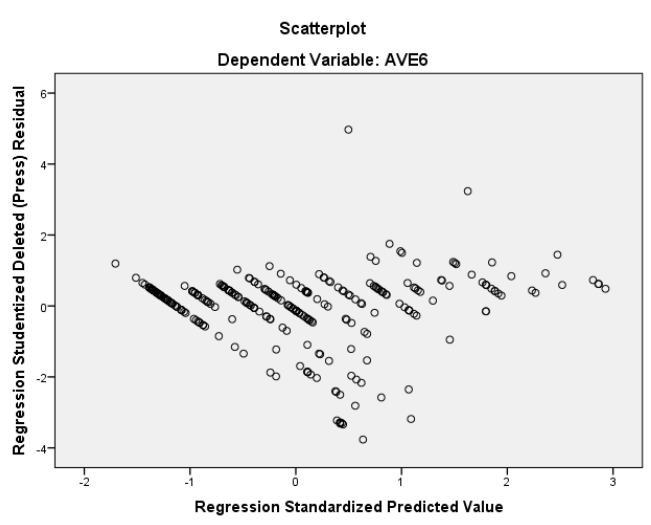

Fig. 1. Scatterplot.

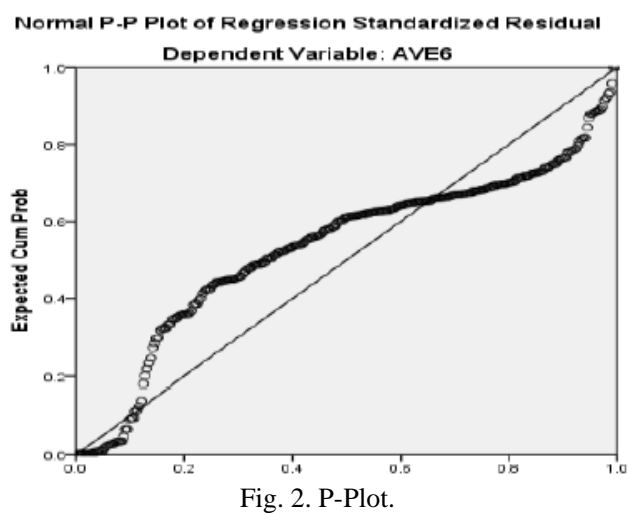

TABLE III: MULTICOLLINEARITY

\begin{tabular}{|c|c|c|}
\hline Model & \multicolumn{2}{|c|}{ Collinearity Statistics } \\
\hline & Tolerance & VIF \\
\hline (Constant) & & \\
BOSAVR & 0.986 & 1.014 \\
MDAVR & 0.964 & 1.037 \\
FINAVR & 0.994 & 1.006 \\
MGTAVR & 0.963 & 1.038 \\
NETAVR & 0.989 & 1.012 \\
\hline
\end{tabular}

TABLE IV: ANOVA TABLE

\begin{tabular}{|c|c|c|c|c|c|}
\hline Model & Sum of Squares & df & Mean Square & $\mathrm{F}$ & Sig. \\
\hline 1 Regression & 242.073 & 5 & 48.415 & 236.055 & $0.000^{\mathrm{b}}$ \\
\hline Residual & 56.197 & 274 & .205 & & \\
\hline Total & 298.269 & 279 & & & \\
\hline
\end{tabular}

a. Dependent Variable: AVR6

b. Predictors: (Constant), AVR5, AVR4, AVR3, AVR1, AVR2

The scatter plot is basically used as a tool to identify the sequential patterns in the occurrence of the entrepreneurship problems. The tolerance values (greater than 0.10) and VIF values (less than 10) from this data are both satisfactory [34].

The significance of F-test should be less than 0.05 and in Table VI, the significance of BOSAVR, FINAVR, and NETAVR are less than 0.05, while MDAVR and MGTAVR are more than 0.05 . Which means that business operation and service problems, finance problems, and networking problems influence the independent variable, entrepreneurship project. From Table V it shows that business operation and service problems, motivation and demand problems, finance problems, management problems and networking problems explained $80 \%$ of the influence.

TABLE V: MODEL SUMMARY

\begin{tabular}{|l|l|l|l|l|}
\hline Model & $\mathrm{R}$ & $\mathrm{R}$ Square & $\begin{array}{c}\text { Adjusted R } \\
\text { Square }\end{array}$ & $\begin{array}{c}\text { Std. Error of the } \\
\text { Estimate }\end{array}$ \\
\hline 1 & $0.901^{\mathrm{a}}$ & 0.812 & 0.808 & 0.45288 \\
\hline
\end{tabular}

\begin{tabular}{|c|c|c|c|c|c|}
\hline \multirow[t]{2}{*}{ Model } & \multicolumn{2}{|c|}{$\begin{array}{c}\text { Unstandardized } \\
\text { Coefficients }\end{array}$} & $\begin{array}{l}\text { Standardized } \\
\text { Coefficients }\end{array}$ & $\mathrm{t}$ & Sig. \\
\hline & B & Std. Error & Beta & & \\
\hline (Constant) & 1.041 & 0.213 & & 4.894 & 0.000 \\
\hline BOSAVR & 0.939 & 0.028 & 0.897 & 33.994 & 0.000 \\
\hline FINAVR & -0.093 & 0.043 & -0.057 & -2.177 & 0.030 \\
\hline NETAVR & -0.247 & 0.048 & -0.137 & -5.205 & 0.000 \\
\hline
\end{tabular}

a. Dependent Variable: EPAVR

\section{DISCUSSION AND CONCLUSION}

The results of this research paper indicates that the solution to business operation and service problems, motivation and demand problems, finance problems, management problems, and networking problems are, first, the period of around two weeks' time to learn the theories of starting a business in detail should be increased to at least one month thus, the students are able to attain deeper entrepreneurial skills. Second, before running the entrepreneurship project, the students should be encouraged to take a mentorship project or entrepreneurship workshop to acquire knowledge from real experiences of businessmen. For taking a mentorship project, we suggest the students to find businessmen who are willing to mentor the student in every field of business. Besides that, they can attend the entrepreneurship workshop held in their own university. In addition, since President University is located in Jabodetabek (Jakarta, Bogor, Depok, Tangerang, Bekasi), specifically in Jababeka, they could cooperate with Jababeka Innovation Center to enhance the entrepreneurship skills of the students.

Entrepreneurship project is made to enhance university students in entrepreneurial skills. Therefore, University students should be supported by positive learning environment so it can create independent character, initiative action, goal oriented, and collaborative personality students.

Learning about entrepreneurship project is an important part in terms of entrepreneurship education. The data analysis in this research indicates that there are five problems faced by doing their entrepreneurship project in business school in Jabodetabek (Jakarta, Bogor, Depok, Tanggerang, Bekasi). In most companies, the most common divisions are production, marketing, management, finance, and information technology. Those problems are commonly faced by students doing their entrepreneurship projects as well.

From the Adjusted R Square we found out that most of 
the research variables have covered the major problems $(80 \%)$. Though there is still $20 \%$ of the research which hasn't been covered. Therefore, we hope that our research can be useful for other researchers researching on common grounds.

\section{ACKNOWLEDGMENT}

The authors would like to give thanks to the Almighty for the blessing for completing this research paper. Thanks also to the supervisor, Mr. Suresh Kumar, for being such a big help in compiling and directing this research paper. The authors are grateful to the respondents in Jakarta, Bogor, Depok, Tangerang, Bekasi (Jabodetabek-Indonesia) business schools who kindly gave their time for giving feedback through the questionnaires. Last but not least, the authors would like to thank their beloved parents and friends who had been giving their support in finishing this research.

\section{REFERENCES}

[1] S. Shane, Two theories of entrepreneurship: alternative assumptions and the study of entrepreneurial action, 2003.

[2] H. Jolanda. (2008). International Entrepreneurship: An Introduction, Framework and Research Agenda. [Online]. 23(4). Available: http://www.entrepreneurship-sme.eu/

[3] S. Shane, E. A. Locke, and C. J. Collins, "Entrepreneurial motivation," Human Resource Management Review, vol. 23, no. 15, 2003.

[4] G. G. Palma, Entrepreneurship for Better Indonesia, 2012.

[5] S. Eman, The application of APBL (authentic problem-based learning) to enhance generic entrepreneurial competencies in a basic chemistry course, 2008.

[6] D. B. Audretsch and M. keillbach, Entrepreneurship, Growth, and Restructuring, 2006.

[7] W. Naude, "Does entrepreneurship matter? The entrepreneurial function in developing countries," in Proc. 15th Conference of the Association for Heterodox Economics, London, 4-6 July, 2013, p. 2.

[8] Davidsson, "The use of global entrepreneurship monitor data in academic research: A critical inventory and future potentials," International Journal Entrepreneurial Venturing, vol. 43, no. 4, 2005.

[9] A. V. Bhide, "Does entrepreneurship matter? The entrepreneurial function in developing countries," in Proc. 15th Conference of the Association for Heterodox Economics, London, 4-6 July, 2013, p. 31.

[10] Kuratko and Hodgetts, "Entrepreneurship education: Emerging trends and challenges for the 21st century," 2003 Coleman Foundation White Paper Series for the U.S. Association of Small Business \& Entrepreneurship, vol. 39, no. 2, 2004.

[11] A. Zoltan and D. Storey, "Entrepreneurship and economic development: Theory, evidence and policy," Discussion Paper Series, IZA DP No. 7507, vol. 20, no. 7, 2004.

[12] R. Hausmann and D. Rodrik, "Entrepreneurship, externalities and development: An austrian critique of the hausmann-rodrik new argument for industrial policy," New Perspectives on Political Economy, vol. 3, no. 1, 2007.

[13] M. Minniti and W. Naudé, "Entrepreneurship and economic development: Theory, evidence and female entrepreneurship in development," 2010.

[14] M. N. Shahidi and A. Smagulova, "The challenges of entrepreneurship in the dynamic society," Central Asia Business, vol. 1 , no. $1,2008$.

[15] Z. J. Acs and D. B. Audretsch, "Entrepreneurship, Innovation and Technological Change," Foundations and Trends® in Entrepreneurship, vol. 50, no. 4, 2005.

[16] A. Gibb, "Content of entrepreneurship education," in Entrepreneurship in Entrepreneurship Education, vol. 20, no. 3, E. Ruskovaara, T. Pihkala, T. Rytkölä, and J. Seikkula-Leino, Eds. 2005.

[17] L. Remes, "Content of learning," in Entrepreneurship in Entrepreneurship Education, vol. 20, no. 4, E. Ruskovaara, T. Pihkala, T. Rytkölä, J. Seikkula-Leino, Eds. 2003.

[18] Steyaert and Katz, "A way of teaching and learning," in Entrepreneurship in Entrepreneurship Education, vol. 20, no. 4, E. Ruskovaara, T. Pihkala, T. Rytkölä, J. Seikkula-Leino, Eds. 2004.

[19] Berglund and Johansson, "Content of learning," in Entrepreneurship in Entrepreneurship Education, vol. 20, no. 4, E. Ruskovaara, T. Pihkala, T. Rytkölä, J. Seikkula-Leino, Eds. 2007.
[20] W. L. Megginson, "Risk tolerance: A perspective on entrepreneurship education," 2008.

[21] C. M. Reinhart and K. S. Rogoff, "Financial and sovereign debt crises: some lessons learned and those forgotten. Financial crises: causes, consequences, and policy responses," IMF Working Paper, vol. 25 , no. 28 , pp. 2-25, 2012.

[22] Sabri, "Effects of financial wellness on the relationship between financial problem and financial productivity," World Applied Science, vol. 8 , no. 50,2008 .

[23] Entrepreneurship education: Emerging trends and challenges for the 21st century, Coleman Foundation White Paper Series, vol. 39, no. 26, 2003.

[24] S. P. Robins and M. Coulter, Management, 9th ed. United States of America: Pearson, 2007, ch. 1, p. 53.

[25] K. Philip and A. Gary, Principles of Marketing, 11th ed. Upper Saddle River, New Jersey: Pearson, 2008, ch. 1, p. 5.

[26] Keefe, “American Marketing Association's 2004 Definition of Marketing," 2004.

[27] N. K. Malhotra, Basic Marketing Research: A Decision Making Approach, 3rd ed. Upper Saddle River, New Jersey: Pearson, 2005, ch. 2 , p. 74.

[28] J. Heizer and B. Render, Operation Management, 10th ed. Upper Saddle River, New Jersey: Pearson 2011, ch. 1, p. 34.

[29] R. Murthy, Production and Operations Management, 2nd ed. Anandpur: New age, 2012. ch. 1, pp. 2.

[30] L. Suemarriott, Enterprise: Entrepreneurship and Innovation, vol. 444, no. 91, 2006.

[31] P. A. Lawler, The Problem of Technology, vol. 31, no. 1, 2004.

[32] United Nations Industrial Development Organization, UNIDO, Developing Rural and Woman Entrepreneurship, vol. 34, no. 13, 2003.

[33] R. R. Frerichs, Rapid Surveys, vol. 44, no. 1, 2008.

[34] H. Robert, Handbook of Univariate and Multivariate Data Analysis and Interpretation with SPSS, London, New York, 2006, ch. 15, p. 290.

[35] N. Katz et al., "The dynamic occupational therapy cognitive assesment for children: A new instrument for assesing learning potential," American Journal of Occupation Theory, pp. 41-52, 2007.

[36] R. Beaumont, "An introduction to principal component analysis \& factor analysis using SPSS 19 and R (psych package)," Factor Analysis and Principal Component Analysis (PCA), vol. 24, no. 8-9, 2012.

[37] N. K. Malhotra, Marketing Research: An Applied Orientation, 6th ed Upper Saddle River, New Jersey: Pearson, 2010, ch. 19, p. 638.

[38] W. Brett, A. Onsman, and T. Brown, "Exploratory factors analysis: A five-step guide for novices," Australian Journal of Paramedicine, vol. 8 , issue 3, pp. 6-10, 2010.

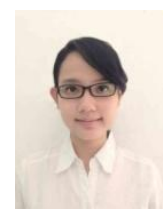

Kerenhapukh Sugiarto was born in Central Java, Indonesia on December 10, 1992. She is an undergraduate business administration student in President University, West Java, Indonesia.

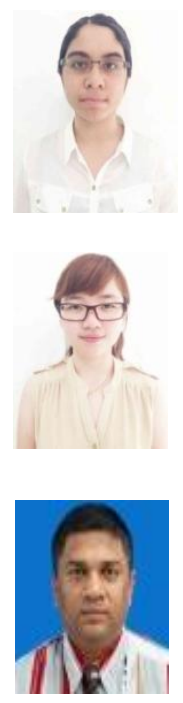

Honey Naresh Samtani was born in Jakarta, Indonesia on January 9, 1996. She is an undergraduate business administration student in President University, West Java, Indonesia.

Stephanie Louissa Amaris was born in Jakarta Indonesia at March 26, 1993. She is an undergraduate business administration in President University, West Java, Indonesia. Yayasan Vijaya (Vijaya Foundation) in 2004-2008. He is $\mathrm{He}$ is a member of Association of Business Administration Indonesia. currently working as a lecturer of President University.

Suresh Kumar was born in Tanjungbalai, North Sumatra, Indonesia on September 7, 1976.

Suresh Kumar was an executive director of Chamber of Commerce and Trade of Tanjungbalai Municipality from 